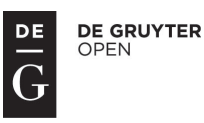

\title{
Internal Quality Process Management Evaluation IN Higher EDUCATION BY STUDENTS
}

\section{Lucie Vnoučková ${ }^{1}$, Hana Urbancová ${ }^{2}$, Helena Smolová ${ }^{3}$}

\begin{abstract}
With the increasing importance of higher education, there is also growing public concern about its productivity. Therefore, the aim of the study is to evaluate the key internal quality management processes by student evaluation and to reveal the key factors of an effective internal quality process management. The indicators used are based on student satisfaction with the education process. The results are based on a quantitative survey using questionnaire data collection within a sample of students, and qualitative research within target groups. Descriptive statistics and two dimensional statistical methods were used to evaluate the quantitative results. The results show student evaluation of five key areas of the internal quality process management evaluation: leadership and strategic planning, student and stakeholder focus, measurement of student learning outcomes, human resource planning and educational process management. A limitation of the study is its narrow focus on a case study of a single private university.
\end{abstract}

\section{Keywords}

Internal Quality, Assessment, Process, Management, Education, University

\section{Introduction}

In all developed countries, and in the Danube countries as well, human resource development is considered one of the key areas vital for the success of every economy and society. An economy cannot work without qualified human resources. Education and its development thus becomes a cornerstone for the functioning of the economies of the

\footnotetext{
${ }^{1}$ University of Economics and Management, Nárožní 2600/9a, 15800 Prague, Czech Republic. E-mail: lucie.vnouckova@vsem.cz.

${ }^{2}$ University of Economics and Management, Nárožní 2600/9a, 15800 Prague, Czech Republic. E-mail: hana.urbancova@vsem.cz.

${ }^{3}$ University of Economics and Management, Nárožní 2600/9a, 15800 Prague, Czech Republic. E-mail: helena.smolova@vsem.cz.
} 
countries in the region of the former Danubian Monarchy. Human resource education can be understood as a system of linked strategies, methodologies and decision-making, the purpose of which consists in the management and development of the human potential for organisations and whole economies to achieve their strategic objectives; however, it is also necessary to respect educational requirements and aspirations, and it is important for every state or economy, regardless of its size.

It is generally true that a higher education level helps the development of any society in all countries of the world. The emphasis in this sector is currently on increasing the quality of the educational process, increasing the employability of graduates, improving interdisciplinarity of individual branches, etc. The sector is increasingly being monitored by representatives of the Ministry of Education at the national level, international accreditation organisations and institutions and also by representatives of organizations and other institutions at the national as well as European level. The reason for this is primarily that higher education helps to develop the given economy and forms the essential basis for sustainable growth.

The general aim of higher education, in the Czech Republic and in the Danube region as well, is, first of all, to achieve complex knowledge and skills for an increasing number of inhabitants. The character of education and higher education institutions has significantly changed and adapted to new quantities and desired skills and knowledge of students with more diverse previous education, profile and background compared to the era ten years ago. On the other hand, the transformation is not yet finished, as there are still significant changes in society and new demands for graduates occur. Furthermore, higher education institutions still face problems when it comes to qualified staff and management. The current preference for educational quality within higher education focuses on the emphasis on the specific competencies development, which are exercisable in practice, the increase of co-operation with practice. It is necessary to design sophisticated structures for studying programs, and using outcomes from learning helps improve the continuity of individual subjects within the curriculum and reduces duplication between them. The pedagogic self-reflection of teachers and an understanding of how students study is also crucial these days. Furthermore, overall improvement of education quality is necessary.

The paper presents the procedure of internal quality audits at a university in the Czech Republic and introduces process management as the key element of quality assurance in higher education. Internal audits provide information to help managers and staff in making decisions and evaluating necessary improvements in the management process of the university. Process understanding and process improvement form the elements of quality organisation (Ewell, 1993). Processes are the steps by which we add value to inputs to produce outputs. The paper shows that the necessary processes of a higher education institution can be systematically described and audited.

Recently, private higher education institutions have been focusing on quality management as a tool to establish and sustain a competitive advantage and to improve economic performance (Lee, 2016). However, it is not easy to determine the appropriate standard level of quantity and the range of information that would provide sufficient data for the process of an internal quality assessment. Incorrectly prepared documentation and data 
can be a source of misunderstanding and create barriers in internal communication and the evaluation of quality (Grudzień and Hamrol, 2016).

The paper is structured as follows. The next section reviews the literature on the searched theme. Section III focuses on materials and methods used to research the theme. Section IV presents the results. Section V provides discussion of the results with current researches and theory on the theme. Finally, section VI consists of concluding remarks.

\section{Theoretical Background}

Universities and colleges, as well as other organizations, operate in a competitive environment. Lomas (2004) holds the opinion that, if any educational institution wants to survive, develop and thrive in the environment, it must continually try to provide a better product and improve the services of the organization as a whole. Todorut and Bojincă (2013) claim that universities in the third millennium will not only represent the expansion of existing structures and requirements, but also the development of completely new structures, which will reflect more precisely the actual requirements of stakeholders. One way might be, for example, fulfilling various quality standards, implementing and maintaining processes of the total quality management and certification of these processes (Aly and Akpovi, 2001; Kluse, 2009). Many studies and research in the past have already proved that TQM is nothing new for the academic environment, as it is a constantly evolving requirement (for example, Wilkinson and Witcher, 1993). Also, Dumond and Johnson (2013) state that universities very often resort mainly to AACSB or ISO 2000 standards, but there also exist different variants. Whether an educational institution chooses any of the options, the areas they should concentrate on are similar, but of course not exactly the same.

More specifically, much research has proved that teachers mainly represent the key attribute leading to the efficiency and progress of students (see, for example, Harford, 2010; Rothstein, 2008; Klem and Connell, 2014; Sacilotto-Vasylenko, 2013). Klem and Connell (2014) add that, if students perceive their teacher as a person purposefully creating a meaningful, well-structured learning environment with clear, adequate and fair rules and expectations, they very often experience high involvement in the teaching process and the functioning of the whole educational institution. Also, Hinde-McLeod and Reynolds (2007) highlight the importance of high, but also adequate, expectations (by teachers) concerning the individual learning abilities of students. The same authors also add that the absence of any type of discrimination and conversely the existence of mutual respect between a teacher and a student is also important.

Teachers form furthermore one of the groups that participate in the implementation of a curriculum (Saidu and Saidu, 2015), whose appropriate setting is a very important aspect of the perceived quality of educational institutions. According to Saidu and Saidu (2015), the other groups implementing and further utilizing a curriculum are students, administrative and other staff of universities and colleges, as well as various interested public and private organizations and individuals. In order to adequately determine the whole framework of a curriculum, it is absolutely necessary for there to be detailed knowledge of skills, knowledges, processes and results for each of the different learning stages (Groundwater and Mockler, 2003). Then, each offered subject must be formulated 
to reflect the current demands of the labour market (Rahman et al., 2004) thus being linked unambiguously to practice (Thompson, 2000; Clapton and Cree, 2004). Saidu and Saidu (2015) also highlight, for example, the importance of other study materials that might significantly improve and increase the efficiency of the final understanding of the subject matter students are going through.

Nikel and Lowe (2010) simply summarize the mentioned points that should be taken into consideration, when evaluating the quality of education, into seven dimensions: Effectiveness, Efficiency, Equity, Responsiveness, Relevance, Reflexivity and Sustainability.

The standards and guidelines for quality assurance have been developed for the use of higher education institutions and quality assurance agencies working in the EHEA, covering the key areas relating to quality and standards. The goal of quality assurance requirements is to guide and assist higher education institutions in developing their own quality assurance systems, as well as to contribute to a common frame of reference. Standards and guidelines should not give orders as to practice but can provide guidance and assistance for those for whom such activities are important. (ENQA, 2004). Across the European Union and EHEA, quality assurance requirements differ from national to international standards and guidelines, although terminologies may change, quality management is in principle similar in different universities (Holm, Vuorisalo and Sammalisto, 2015). A university is a complex system, which consists of many variables and all of these elements closely interact with external factors. The business environment forces universities to look for increasingly efficient working methods. Total Quality Management (TQM) has been one of the most applied organisational change methods in the last two decades. It is focused on increasing an organisation's effectiveness by setting quality objectives (Lapina, Kairiša and Aramina, 2015). The key concept of TQM is the satisfaction of the customer connected with the continuous improvement of repetitive processes supported by innovation. Customer-oriented TQM can positively improve the organisation's competitiveness and performance. TQM influences key organisational aspects such as strategy, structure and culture (Powell, 1995; Roldán and Leal-Rodriguez, 2012).

Typically, for quality assurance at a higher educational institution, the following data are required for any quality assurance or accreditation: information on the institution's governance and administration, procedures and policies, vision and mission statements, institutional integrity, description of educational programs and teaching and support staff, financial and technical resources (EUA, 2008). The university's procedures for assuring quality in teaching, learning and assessment are designed to reflect: the mission of the university, the complexity, diversity and structure of the university, community, supportive and participative environment, the internal quality assurance procedures, a proportionate approach to learning and teaching process and to assessment.

This study, motivated by the recognition that internal quality process management evaluation and thus the success of the educational institution and the whole economy always hinges on student learning outcomes, focuses on one of the key factors in efficiency of educational and learning process: student perception of internal quality process management. Current concepts of the evaluation of internal quality process management may be considered to lack concrete activities focused on students. Therefore, an investigation into 
the practical perception of internal quality process management evaluation is necessary. The survey presented in this paper is focused on the key areas of internal quality process management evaluation evaluated by students, and thus reveals the actual current approach which should be taken by educational institutions to develop themselves to reach competitiveness and a student-centred approach.

\section{Materials and Methods}

This paper was prepared using the method of analysing secondary and primary resources and knowledge synthesis. As regards secondary resources, scientific monographs and articles dealing with the topic were analyzed. Additionally, materials and methods on higher education quality management were searched and reviewed. Websites of institutions that actively deal with the analyzed issue were also used. In order to cover all relevant studies, a variety of keywords for education, quality, learning, management, development and similar were used. The research is descriptive and empirical as to its nature because the primary data were collected using the survey method through the fact-finding techniques such as questionnaires and interviews.

The data for the evaluation of current management of education and learning in the Czech private university were collected within a primary quantitative survey by means of questionnaire investigation. The survey was carried out among students and academic staff. The student data comprised a total of 2,265 students. The evaluated subjects contained the areas of Business Economics, Economics, Management, Marketing and Human Resource Management. Only students who passed the entire education and evaluation process of the mentioned selected areas took part in the survey. The data were collected using CAPI (computer assisted paper interviewing) and CAWI (computer assisted web interviewing) and subsequently processed using statistical software; incomplete questionnaires were deleted. The final data source was analyzed according to identification questions, and a descriptive statistic was used.

The data were collected and analyzed in three trimesters (September to June) in the Academic Year 2016/2017. In the first trimester (September to December), 793 students participated in the questionnaire survey, in the second trimester (January to March), 814 students were questioned and in the third trimester (April to June), 658 students were questioned. Only those students who regularly and periodically attended classes took part in the survey (participation in classes is voluntary for students, not all students attended classes or participated in the research). The results thus do not evaluate students who did not have the overall knowledge and experience with the entire process of education and tuition. Only students who attended all lessons, seminars and lectures were part of the sample.

The respondents were structured as follows:

- Students' gender: 841 (37.13\%) men, 1414 (62.43\%) women, (10 students did not answer);

- Students' professional experience: 1067 (47.11\%) work in the area of study, 1177 $(51.96 \%)$ do not work, (21 did not answer); 
- Students' future intention to work in the area of study: 1213 (53.77\%) plan to work in the area of studied subjects, $338(14.98 \%)$ do not plan to work in the area of studied subjects and the remaining ones (31.13\%) do not know.

The research was designed to map the quality of education and the quality of internal educational quality management in the selected university. The data collection instrument included questions to measure education activities of the university in focus. The questions were designed based on theories (see the theoretical background) and similar research studies. Each student filled in a questionnaire for each subject which s/he participated in. Students evaluated all the compulsory subjects and all optional subjects they had attended. Optional subjects are part of the studies only of full-time students. Part-time students attended and evaluated only compulsory subjects. Students always filled in the questionnaire in the last lecture of each subject.

The questionnaire addressed three main areas (other than identification questions). These were lessons and their organisation, technical and technological support and their content, the course/subject and its structure, usefulness and the teacher's quality. Other than the quality of education, the questionnaires also evaluated study materials, texts and presentations, the teacher's personality and abilities, the technology used in the education process, connection with practice, technical and organizational facilities and equipment, students' learning outcomes, expectations and overall usefulness of the study.

The presented paper evaluates both a formative and summative internal quality evaluation of the education process at the selected university. The evaluation aims to reveal the level of internal management of the education quality and active participation of students based on students' perceptions in the studied period. The reliability of the study is supported by a multiple assessment of each attribute.

Respondents' reactions to target statements and their attitudes to the given matter were restricted by offering a set of several statements. The extremes of the five-point scale represented bipolar concepts of the evaluation dimension. All the questions were measured on the Likert type scale with verbal anchors in 1 (strongly agree) and 5 (strongly disagree) or, provided it was not possible to favour either of the sides, a median, neutral value could be selected (the median value was characterized by number 3 ). The scale permitted not only specification of respondents' attitudes, but also specification of their intensity.

The paper focuses on a more in-depth discussion of the concept of higher education quality and investigating the main approaches of the participating university to the internal quality management process. All the primary data were evaluated using descriptive statistics. In addition, dependence among qualitative characteristics was tested to see whether there are relations between searched attributes, to verify the obtained data and their further analyses (Hendl, 2006). Two-dimensional statistics was used using the correlation coefficient to reveal relations between searched attributes. Statistically significant results were presented at the significance level of 0.05 . To evaluate the results, IBM SPSS statistics was used. The paper's aim is to evaluate the key internal quality management processes by student evaluation. The searched internal quality processes were designed based on the ACBSP standards (ACBSP, 2016 and 2017). For the construction of the paper, the first two standards 
were used as one, as many of the measurable variables are interconnected in this standard. Also, the evaluation of these standards by students has several limitations, as not all students may perceive and evaluate them. Therefore, the paper evaluated five areas of the internal quality management process: (1) leadership and strategic planning, (2) student and stakeholder focus, (3) measurement of student learning outcomes, (4) human resource planning and (5) educational process management. The processes and the system of measurements used for evaluation by students are described below. For all areas, descriptive statistics and correlation analysis were used to review the survey output based on the stated results.

The main hypothesis in this paper is H0: The internal management quality of education process is not perceived by students.

\section{Leadership and Strategic Planning}

The internal quality process management in the area of leadership and strategic planning is for the purposes of the study conducted based on a student survey defined and evaluated by a systematic approach, strategic directions, measurable objectives, performance expectations of the institution, creating and sustaining values, performance expectations through the key student and program performance requirements and innovation and creativity. In order to measure outcomes in the searched area, the following hypotheses were stated: H1: There is no dependence between the students' perception of an adequate study plan in the study program and the fulfilled expectations of students.

$\mathrm{H} 2$ : There is no dependence between the students' perception of a program connected with practice and its perception as beneficial and valuable.

\section{Student and Stakeholder Focus}

The internal quality process management in student and stakeholder focus is for the purposes of the study conducted based on a student survey defined and evaluated by an awareness of the needs of segments, stakeholder relations, feedback, increasing customer satisfaction, effective communication and quality education.

To evaluate factors in the area of student and stakeholder focus, students expressed their opinion on the Likert scale on their perceived level of lectures, style of explanation, level of understanding, tempo of lessons and seminars, attractiveness of lessons and program, atmosphere at school and in lessons, connection between theory and practice and evaluation of practicing during seminars and workshops. The results are presented in the table showing the averages and standard deviation of the responses of students in the searched area.

\section{Measurement of Students Learning Outcomes}

The internal quality process management in the area of student learning outcomes is for the purposes of the study conducted based on a student survey defined and evaluated by data set at the beginning of a course, assessment, learning objectives and results, process comparison, learning and improvement. 
In order to measure the outcomes in searched area, the following hypotheses were stated: H3: There is no dependence between the students' perception of a lesson as understandable and a suitable pace of explanation.

H4: There is no dependence between the students' perception of a lesson as understandable and students' perception of a suitable style of explanation.

H5: There is no dependence between the students' perception of a lesson as adequate and students' perception of a suitable style of explanation.

Additionally, to evaluate factors in the area of student and stakeholder focus, students expressed their opinion on the Likert scale on their perceived level of adequacy of requirement on exams and level of understanding ability of learning outcomes.

\section{Human Resource Planning}

The internal quality process management in the area of human resource planning is for the purposes of the study conducted based on a student survey defined and evaluated by a level of academic staff and its development, support of grants, projects and primary on applied research.

In order to measure the outcomes in the searched area, the following hypotheses were stated:

H6: There is no dependence between the students' perception of the teacher as using modern teaching techniques and students' perception of tuition focused on practice.

H7: There is no dependence between the students' perception of the teacher as thoughtful and adequate explanations by the teacher.

H8: There is no dependence between the students' perception of the teacher as being able to attract attention and students' perception of tuition focused on practicing.

\section{Educational Process Management}

The internal quality process management in the area of human resource planning is for the purposes of the study conducted based on a student survey defined and evaluated by education design and delivery, IT, systems, support processes, operational processes, job placement and societal changes. These areas were tested by students' responses, which they expressed on the Likert scale.

Additionally, the outcomes in the searched area were measured by the following hypotheses:

H9: There is no dependence between the students' perception of the teacher as thoughtful and the students' opportunity to express their opinions.

H10: There is no dependence between the students' perception of the teacher as motivating and students' perception of tuition focused on practicing.

The above-mentioned statements and hypotheses are evaluated and discussed in the chapter "Results" and summarized in the conclusions of the paper. 


\section{Results}

The objective of this chapter is to evaluate the results obtained from the primary survey. The results of the quantitative research have been statistically evaluated and recommendations have been formulated upon this basis. The results are presented according to the five evaluated areas of the internal quality process management described in the theoretical background and methods.

\section{Leadership and Strategic Planning}

As to the paper's focus on the key areas of the internal quality process management in the searched university, students were asked about the core of the management process, leadership and strategy. As not all students may be familiar with strategies, the study asked them about the connection and impact of strategic planning and leadership on their study programs and plans. Therefore, the area of leadership and strategic planning was evaluated in the student survey based on students' perception of the structure of the study programs they are studying or plan to study in the following degree. Also, they were asked about their expectations from the program which were evaluated together with students' perception of the usefulness of their study program and subjects in their future job positions. All these variables were evaluated on a good level. The average evaluation of the study program (on a 5-point scale where 1 is the best) was 1.6, for usefulness of the program and subjects it was 1.68 , for usefulness for their job it was 1.5 .

Selected variables were also tested by the correlation coefficient as to whether there are significant relations. Two statistically significant dependencies were found. The results are shown in the Table 1 below.

Table 1: Hypotheses related to the leadership and strategic planning

\begin{tabular}{|l|c|c|}
\hline Hypotheses & Pearson's correlation & p-value \\
\hline Adequate study program - fulfilled expectations & 0.511 & 0.000 \\
\hline Practically oriented program - beneficial, valuable program & 0.601 & 0.000 \\
\hline
\end{tabular}

Source: Authors' processing

The analysis shows that there are statistically significant relations between a study program perceived as adequate and fulfilled expectations from the study program by students. Therefore, it is necessary to know and meet the expectations of students in order to prepare a suitable and adequate study program (study plan) for them.

Also, students in business programs evaluate practically oriented programs as best. The test found relations between programs oriented on practice and student perception of valuable and beneficial programs.

Thus, it is necessary in strategic planning to search and know the expectations of students and focus on designing practically oriented study programs. 


\section{Student and Stakeholder Focus}

The second evaluated area is closely connected to the strategy as it should be formulated based on students and stakeholders needs. According to students' opinions, the most discussed variables presented and perceived by students, stakeholders and public are evaluated positively. The presented research searched for the most discussed determinants of student and stakeholder orientation and satisfaction. These are level of lectures, explanation on seminars, attractiveness of program, atmosphere at school and the connection between theory and practice. The average of those variables is 1.58 . Modus and median is always 1 . Thus, students' perception of these areas is quite positive. Detailed results are presented in Table 2 .

Table 2: Evaluated areas related to student and stakeholder focus

\begin{tabular}{|l|c|c|c|c|}
\hline & AVG & MOD & MED & STD \\
\hline Lectures are adequate & 1.68 & 1 & 1 & 0.82 \\
\hline Style of explanation is adequate & 1.54 & 1 & 1 & 0.81 \\
\hline Explanation is understandable & 1.47 & 1 & 1 & 0.75 \\
\hline Tempo suits me & 1.59 & 1 & 1 & 0.82 \\
\hline The way of explanation suits me & 1.62 & 1 & 1 & 0.85 \\
\hline Program is attractive & 1.60 & 1 & 1 & 0.77 \\
\hline Perception of positive atmosphere & 1.51 & 1 & 1 & 0.79 \\
\hline Connection between theory and practice & 1.51 & 1 & 1 & 0.79 \\
\hline Attention on practicing & 1.67 & 1 & 1 & 0.88 \\
\hline AVG & 1.58 & - & - & - \\
\hline
\end{tabular}

Source: Authors' processing

Standard deviations oscillate around 0.8 in all studied variables. Students' perception on all searched determinants is quite stable and united.

\section{Measurement of Student Learning Outcomes}

Student learning outcomes are one of the most important measures at all universities. Therefore, the basic determinants were also evaluated by students. As it is possible to see in Table 3, students perceive the study process as caring about their understanding. The average evaluation on the scale is 1.44 and modus and median are 1 . The requirements for exams are perceived on a similar level. The average value on the five-point scale is 1.93 and again, modus and median are always 1 .

Based on the results presented in Table 3, relations between the selected determinants of student learning outcomes were tested. The significant conditions of successful student learning outcomes and understandable lessons are suitable tempo and style of explanation during lectures and seminars. Therefore, to reach and maintain learning outcomes of students, it is necessary to pay special attention to explanations and teachers' attitude on courses. 
Table 3: Evaluated areas related to students learning outcomes

\begin{tabular}{|l|c|c|c|c|}
\hline Learning outcomes & AVG & MOD & MED & STD \\
\hline Requirements for exams are adequate & 1.93 & 1 & 1 & 0.86 \\
\hline Care about student understanding & 1.44 & 1 & 1 & 0.72 \\
\hline AVG & 1.68 & - & - & - \\
\hline
\end{tabular}

Source: Authors' processing

The resultant correlations in Table 4 are quite high and show interconnection between the personality and attitude of a teacher on the learning outcomes of students. Therefore, it is necessary to keep in mind that not only specified outcomes, but also learning process matters in achieving learning outcomes.

Table 4: Hypotheses related to measurement of learning outcomes of students

\begin{tabular}{|l|c|c|}
\hline Hypotheses & Pearson's correlation & p-value \\
\hline Understandable lesson - suitable tempo of explanation & 0.721 & 0.001 \\
\hline Understandable lesson - suitable style of explanation & 0.806 & 0.000 \\
\hline Adequate lesson - suitable style of explanation & 0.589 & 0.000 \\
\hline
\end{tabular}

Source: Authors' processing

\section{Human Resource Planning}

Following the area of student learning outcomes which leads to the personality of a teacher, the area of human resource planning is evaluated. Teacher personality is very important for the quality of business education. Therefore, the skills and expertise of teachers were evaluated by students in the survey.

On the scale, students evaluated teachers at an average value of 1.6 as experts. Their skills were also on a very good level, on average also 1.6. Modes and medians were always 1 . Following these results, correlation analysis was used to find significant relations between the selected determinants. Students positively perceive abilities of teachers to attract them, connect lessons with practice and thoughtful explanation according to student needs.

As it is possible to see in Table 5, statistically significant correlations were found between the practically oriented education and attractiveness of lessons given by a teacher. Also, relations were found between the thoughtfulness of a teacher and adequate explanation and also with the possibility of a student to express his opinion. Those areas, together with the open discussion during lessons and seminars were the highest evaluated determinants of the quality perceived by students. They want to be part of the lecture and see that their needs during the learning process are perceived by the teacher. Additionally, student motivation is related to their perception of the possible use of new knowledge in practice. This practical focus is mostly preferred by students and supports their attention and interest in the educational and learning process.

The technical skills of a teacher, on the other hand, do not matter to students and do not affect the results or perception of a lecture, a teacher or a program as high quality. 
Table 5: Hypotheses related to the human resource planning

\begin{tabular}{|l|c|c|}
\hline Hypotheses & Pearson's correlation & p-value \\
\hline Technical skills of a teacher - lecture usable in practice & 0.115 & 0.004 \\
\hline Thoughtful teacher - adequate explanation & 0.678 & 0.000 \\
\hline Teacher is able to attract attention - lecture usable in practice & 0.471 & 0.000 \\
\hline Thoughtful teacher - opportunity to express opinion & 0.599 & 0.000 \\
\hline Teacher motivates students - lecture usable in practice & 0.491 & 0.000 \\
\hline
\end{tabular}

Source: Authors' processing

Based on the above-mentioned results, it is possible to suggest a student-centred education respecting students' needs. This personal approach of teachers and staff is mostly appreciated by students. It also results in their learning outcomes and the positive reputation of a university. Teachers and staff should be planned, recruited, hired and developed in this way together with a focus on inclusion.

\section{Educational Process Management}

Following the impact of human resources on the educational process, the fifth area focuses on the process as whole. Below, in Table 6, the variables regarding educational process management are evaluated by students. The area was studied by students' perception of the educational process in means of its design, difficulties, benefits and values, connection with practice and support by new technologies and techniques. Other than that, perceived motivation to learn and pass the program was also examined. Most of the variables of the educational process management are rated very high; on the five-point scale, the average is 1.79 and again, modes and medians are 1 in almost all cases. The outstanding values are seen in difficulties of subjects. Students perceive them as mostly moderately difficult. That is a good sign of an adequate setting of study goals and student learning outcomes. Students see them as reachable and have no problems to achieve them. Communication between students and the management of the educational process works well. Details on the evaluation of the searched areas are shown in Table 6.

Table 6: Evaluated areas related to the educational process management

\begin{tabular}{|l|c|c|c|c|}
\hline & AVG & MOD & MED & STD \\
\hline Study program is adequately designed & 1.67 & 1 & 1 & 0.81 \\
\hline Subjects are difficult & 2.47 & 3 & 3 & 0.95 \\
\hline Subjects are beneficial and valuable & 1.60 & 1 & 1 & 0.77 \\
\hline Subjects are connected with practice & 1.85 & 1 & 2 & 1.00 \\
\hline Use of modern technologies & 1.45 & 1 & 1 & 0.71 \\
\hline Use of modern teaching techniques & 2.07 & 1 & 2 & 1.27 \\
\hline Motivation to learn & 1.69 & 1 & 1 & 0.88 \\
\hline AVG & 1.79 & - & - & - \\
\hline
\end{tabular}

Source: Authors' processing 
As it was possible to see from the previous results, standard deviations do not fluctuate much. The differences may be seen in Table 6; i.e. not all the subjects in the evaluated study programs are perceived by students as oriented on practice. The standard deviation of this variable reached 1.0. That is because there are some basic theoretical subjects placed at the beginning of the study program (i.e. Economics Theory). But those subjects are clear preparation for other superordinate subjects, where basic theory is necessary to progress further. Another higher standard deviation may be seen in the variable "Use of modern teaching techniques". Not all teachers use modern teaching techniques, but as was found in Table 5, it does not affect the results, neither in the perception of a teacher as skilled, nor in perception of a subject as usable.

It is possible to summarize that all searched areas are closely connected and it is not possible to manage one without the other. Statistically significant relations which were found supported orientation on students and stakeholders and on a practical orientation of business programs. Learning outcomes can be achieved through open discussion between students, staff and management of the university, which leads to the adequate setting of goals and understanding.

\section{Discussion}

Based on the above-mentioned data, we can summarize that each college and university should be regarded as a service provider with its customers whose interests it is trying to meet, as confirmed also by Lomas (2004). Individual customers, as students, employers, organizations, but also the whole society evaluate the quality of these services (Hutyra, 2008). It is necessary to realize that the quality of education provided by colleges and universities significantly influence the socio-economic and cultural development of each society (Todorut, 2016) worldwide and the researches of Bhuian (2016), Holm, Sammalisto and Vuorisalo (2015), as well as Wang (2014), highlight the fact that in today's global environment, competition among colleges and universities continuously grows, and it is therefore necessary to pay due attention to the evaluation of Internal Quality Process Management. Colleges and universities play an important role when building a strong knowledge-based economy not only for individual countries but also for the whole European continent and they determine the global competitiveness of graduates of the tertiary education (ESG, 2015). Also, the university that provided the results for the article, thereby enabling the creation of a case studies on how to ensure an Internal Quality Process Management Evaluation by students, is continuously trying to achieve the improvement of its educational process quality and its competitiveness at the tertiary market in the sphere of higher education.

The topicality of the issue addressed within this article is also supported by the effort to create the European Higher Education Area (EHEA) established within the Bologna Process and the subsequent European reforms (Brady and Bates, 2016; Prisăcariu, 2014). Its main goal is to create a high quality, transparent and diversified European higher education in order to achieve a strong competitive position in the world (Keçetep and Özkan, 2014). Jarvis (2014) adds that the main mission of ensuring quality of higher education is to create a culture of continuous organizational and professional self-development and 
self-regulation that will ensure the improvement of services in the sphere of the tertiary education and comply with the needs of the global knowledge economy and learning society.

Regulations for universities are settled mainly at the state level, but some of the state regulations are not strict, allowing universities to develop their own internal quality management systems. Individual internal management systems reflect external standards and the processes of internal quality assurance are surprisingly similar (Klenk and Seyfried, 2016).

From the European standards for internal quality assurance of tertiary education institutions (ESG, 2015) and the new Universities Act effective from September 1, 2016, in the Czech Republic, we can also summarize that colleges and universities should implement a policy of quality assurance based on strategic management, pay attention to the quality of their programs, support an active role for students in the teaching process, ensure the fair and transparent recruitment and development of staff, and regularly publish up-todate information about their activities and programs and insist on the Internal Quality Process Management evaluation by students, which is in compliance with findings from the researches of Rahman et al. (2004), Clapton and Cree (2004) and Saidu and Saidu (2015). According to Stimac and Katic (2015), European universities most often have shortcomings in terms of insufficient involvement on the part of students in the teaching process, lack of feedback from students and not publishing evaluation reports. But the analyzed university did not have such problems, because as to feedback from students, there are possibilities of involvement in tuition, and the results of evaluation reports are disclosed to all interested parties. Thus, we can state that the University of Economics and Management is trying to insist on educational process quality and regularly gets feedback from its students and subsequently reflects its results in the strategic planning of its development so as to ensure progress according to ACBSP $(2016,2017)$. The research carried out showed that it is necessary not only at the surveyed university to search and know the expectations of students and focus on designing practically oriented study programs for strategic planning, which is in compliance with the results of Jarvis (2014).

\section{Conclusion}

With regard to the results, we can state that the surveyed university uses modern approaches to monitor the quality of its internal processes, technologies and management within education, which, with some partial discussed exceptions, suits students and teachers, and among students, teachers and the university management, there is appropriately set communication process. The overall results also confirmed the importance of having properly set leadership and strategic planning at the level of the whole university and communication of this sphere towards teachers and students themselves. The results further highlighted the importance and necessity of insisting on the student and stakeholder focus, regularity of evaluation of student learning outcomes and publication of achievements, and, last but not least, it is also necessary to maintain a properly set program of the human resource planning and educational process management that will satisfy teachers as well as students, but also university management and external stakeholders. 
Research outcomes identified and verified that student learning outcomes are one of the most important measures at all universities and showed that a personal approach of teachers and staff is highly appreciated by students. It also results in real student learning outcomes and the positive reputation of a university. Therefore, the teachers and staff must be planned, recruited, hired and developed in this way together with a focus on inclusion. The results revealed significant statistical dependence among personal approach of teachers and staff and quality of learning process.

Students in business programs evaluate the best practically oriented programs. Similarly, student motivation is related to the perception of the future use of new knowledge in their job. This practical focus is preferred by students as well as higher attention and interest in the educational and learning process. Thus, it is necessary in strategic planning to search and know the expectations of students and focus on designing practically oriented study programs. To reach and maintain student learning outcomes, it is necessary to pay special attention to explanation and teacher attitude on courses. The results point at interconnection between the personality and attitude of a teacher and student learning outcomes.

In conclusion, it is necessary to highlight the result that not only specified outcomes, but also learning process matters in achieving learning outcomes. Therefore, it is possible to suggest student centred education respecting students' needs.

The topic of this article is currently relevant for all colleges and universities from the perspective of their presentation for potential students and future employers of graduates and, last but not least, for the reason of evaluating the global quality level of schools. The article also reflects the progress in insisting on quality of the high education system influenced by the management strategy of particular college or university. The article is limited with its narrow focus on a selected university within the Czech Republic, but the results are presented as a case study whose outcomes can help other colleges and universities to ensure an internal quality assessment according to the requirements of national and international accreditation institutions and applicable legislation.

\section{References}

ACBSP. (2017). Obtaining accreditation: A Process Book For Institutions Seeking Initial Accreditation. Kansas, USA: Accreditation council for business schools and programs. Retrieved October 17, 2017, from http://www.nwosu.edu/Websites/NWOSU/images/Academics/Business/Obtaining_Accreditation_Manual_B-G_Hyperlinked.pdf.

ACBSP. (2016). ACBSP standards and criteria for demonstrating excellence in baccalaureate/graduate degree schools and programs. Kansas, USA: Accreditation council for business schools and programs. Retrieved October 17, 2017, from http://c.ymcdn.com/sites/ www.acbsp.org/resource/collection/EB5F486D-441E-4156-9991-00D6C3A44ED1/ACBSP_Standards_and_Criteria_-_Bacc-Grad.pdf.

Aly, N. and Akpovi, J. (2001). Total quality management in California public higher education. Quality Assurance in Education, 9, 127-131.

Bhuian, S. N. (2016). Sustainability of Western branch campuses in the Gulf Region: Students' perspectives of service quality. International Journal of Educational Development, 49, 314-323. 
Brady, N. and Bates, A. (2016). The standards paradox: How quality assurance regimes can subvert teaching and learning in higher education. European Educational Research Journal, 15, 155-174.

Clapton, G. and Cree, V. (2004). Integration of learning for practice: Literature review. Learning for effective and ethical practice. Edinburgh: Scottish Institute for Excellence in Social Work Education.

Dumond, E. J. and Johnson, T. W. (2013). Managing university business educational quality: ISO or AACSB? Quality Assurance in Education 21, 127-144.

ENQA. (2004). Transnational European Evaluation Project - Methodological Reflections. Helsinki: European Network for Quality Assurance in Higher Education. Retrieved October 17, 2016, from http://www.enqa.eu/indirme/papers-and-reports/occasionalpapers/TEEPmethod(1).pdf.

ESG. (2015). Standards and Guidelines for Quality Assurance in the European Higher Education Area. Brussels, Belgium.

EUA. (2008). European University Association. Implementing and using quality assurance: Strategy and practise a selection of papers from the 2nd European quality assurance forum. Brussels, Belgium.

Ewell, P. T. (1993). The role of states and accreditors in shaping assessment practice, in Banta, T. W. (Ed.), Making a Difference: Outcomes of a Decade of Assessment in Higher Education. San Francisco, CA: Jossey-Bass.

Groundwater-Smith, S. and Mockler, N. (2003). Learning to listen: Listening to learn. Division of Professional Experiences, Partnerships and Development, Faculty of Education Social Work [sic], University of Sydney.

Grudzień, L. and Hamrol, A. (2016). Information quality in design process documentation of quality management systems. International Journal of Information Management, 36, 599-606.

Harford, J. (2010). Teacher education policy in Ireland and the challenges of the twentyfirst century. European Journal of Teacher Education, 33, 349-360.

Hendl, J. (2006). Přehled statistických metod zpracování dat: analýza a metaanalýza dat. Praha: Portál.

Hinde-McLeod, J. and R. Reynolds. (2007). Quality Teaching for Quality Learning: Planning through reflection. South Melbourne: Cengage Learning.

Holm, T., Vuorisalo, T. and Sammalisto, K. (2015). Integrated management systems for enhancing education for sustainable development in universities: a memetic approach. Journal of Cleaner Production, 106, 155-163.

Holm, T., Sammalisto, K. and Vuorisalo, T. (2015). Education for sustainable development and quality assurance in universities in China and the Nordic countries: a comparative study. Journal of Cleaner Production, 107, 529-537.

Hutyra, M. (2008). Kvalita ve vzdělávání a její zabezpečování v prostředí vysokých škol. Perspektivy jakosti: čtvrtletník pro získávání poznatků a šiřrení znalostí o managementu jakosti, 1, 8-12. 
Jarvis, D. S. L. (2014). Regulating higher education: Quality assurance and neo-liberal managerialism in higher education - A critical introduction. Policy and Society, 33, $155-166$.

Keçetep, İ. and Özkan, İ. (2014). Quality Assurance in the European Higher Education Area. Procedia-Social and Behavioral Sciences, 141, 660-664.

Klem, A. M. and J. P. Connell. (2004). Relationships matter: Linking teacher support to student engagement and achievement. Journal of school health, 74, 262-273.

Klenk, T. and Seyfried, M. (2016). Institutional Isomorphism and Quality Management: Comparing Hospitals and Universities. Towards A Comparative Institutionalism: Forms, Dynamics And Logics Across The Organizational Fields Of Health Care And Higher Education (Research in the Sociology of Organizations). Emerald Group Publishing Limited, 45, 217-242.

Kluse, C. (2009). TQM and the Government: The Importance of Leadership and Personal Transformation. Journal for Quality \& Participation, 32, 27-31.

Lapina, I., Kairiša, I. and Aramina, D. (2015). Role of Organizational Culture in the Quality Management of University. Procedia - Social and Behavioral Sciences, 213, 770-774. 20th International Scientific Conference Economics and Management.

Lee, M. (2016). Competitive Strategy for Successful National University Hospital Management in the Republic of Korea. Osong Public Health Res Perspect, 7, 149-156.

Lomas, L. (2004). Embedding quality: the challenges for higher education. Quality Assurance in Education, 12, 244-56.

Nikel, J. and Lowe, J. (2010). Talking of fabric: A multi-dimensional model of quality in education. Compare, 40, 589-605.

Powell, T. C. (1995). Total quality management as competitive advantage: A review and empirical study. Strategic management journal, 16, 15-37.

Prisăcariu, A. (2014). Approaches of Quality Assurance Models on Adult Education Provisions. Procedia-Social and Behavioral Sciences, 142, 133-139.

Rahman, H. B. A, Khalifah, Z. B., Arif, S. B., Sirin, R. B., Abidin, H. B. Z. and Sulong, N. B. (2004). Kajian mengenai tahap kualiti pendidikan tinggi dari perpektif pelajar di Universiti Teknologi Malaysia. Pusat Pengajian Penyelidikan. Universiti Teknolgi Malaysia. Monograph. Vol: 75017.

Roldán, J. L., Leal-Rodríguez, A. L. and Leal, A. G. (2012). The influence of organisational culture on the Total Quality Management programme performance. Investigaciones Europeas de Dirección y Economía de la Empresa, 18, 183-189.

Rothstein, J. (2008). Teacher quality in educational production: Tracking, decay, and student achievement (No. w14442). National Bureau of Economic Research.

Sacilotto-Vasylenko, M. (2013). Bologna process and initial teacher education reform in France. International Perspectives on Education and Society, 19, 3-24.

Saidu, S. and Saidu, S. S. (2015). The impact of educational resources on curriculum implementation in Nigeria. Journal of Education, Arts and Humanities, 3, 59-63.

Stimac, H. and Katic, S. (2015). Quality Assurance In Higher Education. Interdisciplinary Management Research, 11, 581-591. 
Thompson, N. (2000). Theory and practice in human services. Buckingham, UK: Open University.

Todorut, A. V. (2016). A New Architecture of Quality in Education. Quality-Access to Success, 17, 60-63.

Todorut, A. V. and Bojincă, M. (2013). Total Quality Management and Quality Culture. Quality-Access to Success, 14, 79-82.

Wang, L. (2014). Quality assurance in higher education in China: Control, accountability and freedom. Policy and Society, 33, 253-262.

Wilkinson, A. and Witcher, B. (1993). Holistic TQM must take account of political processes. Total Quality Management, 4, 47-56. 